\title{
РЕГУЛИРОВАНИЕ ТРАНСПОРТИРОВКИ ГАЗА В СТРАНАХ ЕАЭС
}

\author{
(c) 2020 Хамикоева А. 0. \\ аспирант \\ Санкт-Петербургский государственный экономический университет, Россия, Санкт-Петербург \\ E-mail: alinahamiokeva@mail.ru
}

В статье рассматриваются вопросы современного состояния транспортировки газа по трубопроводам стран участниц ЕАЭС. Роль транспортировки газа в данной интеграции является достаточно важной в силу того, что перемещение товаров и услуг в основном происходит за счет применения инфраструктуры естественных монополий.

Ключевые слова: естественные монополии, транспортировка газа, импорт/экспорт, интеграция, взаимная торговля

Ключевым приоритетом устойчивого развития является свободный рынок. Чем меньше барьеров и ограничений на рынке, тем эффективнее он работает. Именно поэтому в мире образуются экономические объединения, одним из которых является Евразийский экономических союз, включающий Россию, Республику Беларусь, Республику Армения, Республику Киргизия, Республику Казахстан.

Интеграция в ЕАЭС для сравнительно небольших государственных формирований является гарантом обеспечения долгосрочных экономических интересов и экономического роста.

Основными преимуществами присоединения к ЕАЭС являются:

- ликвидация или снижение уровня тарифных и нетарифных барьеров;

- свобода передвижения ресурсов между странами;

- возможность использования энергоресурсов по низким, по сравнению с мировым уровнем, ценам;

- расширение рынка сбыта;

- возможность миграции рабочей сил;

- рост конкурентоспособности национальных экономик.

ЕАЭС это важный органичный элемент мировой экономической архитектуры. Ключевой целью интеграции является создание общих экономических рынков для свободного передвижения товаров, услуг, капитала и т.д. При этом одним из важнейших ресурсов интеграционного объединения ЕАЭС являются запасы углеводородов. Так, в настоящее время Казахстан занимает 22-е место в мире и 3-е место среди стран СНГ после России и Туркменистана по

доказанным запасам «голубого топлива».

Доказанные запасы газа составили около 3,9 трлн. кубометров [2], из них запасы попутного газа 2,6 трлн. кубометров и природного газа 1,3 трлн. кубометров. Природный газ в Казахстане в основном является «попутным», то есть он добывается вместе с сырой нефтью и конденсатом практически на всех месторождения, причем основные месторождения находятся в Тенгизе и Карачаганаке.

Около $80 \%$ потребностей страны в энергии покрывается за счет природного газа. Тем не менее, хотя объем внутреннего производства позволяет Республике удовлетворять свои потребности в газе, некоторые регионы все еще испытывают дефицит газа. Экспорт природного газа в январе-феврале 2019 года достиг 4,9 млрд. кубометров. Основным покупателем казахского газа является Россия.

Ведущим оператором, осуществляющим транспортировку газа по магистральным газопроводам, является национальный оператор АО «КазТрансГаз».

Законодательным основанием для строительства, владения и эксплуатации магистральных трубопроводов является закон о магистральных трубопроводах, который также включает дальнейшие шаги правительства Казахстана по контролю над стратегическими районами страны. Республика Казахстан имеет приоритетное право на долю 51\% (проходящих через Национальную компанию) в любых новых проектах магистральных трубопроводов. Приоритетное право дает Казахстану совместно участвовать с инвесторами в создании и/или строительстве новых магистральных трубопроводов. 
Система нефтегазопроводов Казахстана напрямую связана с транспортной инфраструктурой России.

Согласна законодательству Казахстана, график транспортировки нефти по магистральным трубопроводам разрабатывается в соответствии с соглашениями между владельцем или оператором и компанией по недропользованию, с учетом внутренних потребностей Республики Казахстан в поставках, определенными компетентными органами.

Нормативно-правовая база Республики Казахстан содержит весьма подробный перечень регулируемых услуг в сфере газоснабжения, из которой видны все составляющие конечной цены на газ для потребителей. Необходимо отметить, что в Республике Казахстан в качестве услуг субъектов естественных монополий выделяют услуги по хранению газа (в газгольдерах или подземных хранилищах).

Услуги по транспортировке нефти и газа по магистральным трубопроводам считаются естественными монополиями, для которых заранее определены тарифы, сроки и лимит предоставляемых услуг. Согласно закону, тарифы на регулируемые услуги не должны быть ниже стоимости затрат, необходимых для предоставления услуг.

Особенностью газотранспортной системы Казахстана является то, что она создавалась как технологически взаимосвязанная часть газотранспортной системы СССР. Система была ориентирована на поставку газа из Северной Азии в северные области России, на Украину и Закавказья. В связи с тем, что магистральные газопроводы не были технически соединены между собой, существует проблема перекачки добываемого газа из западной части в южные и северные области страны. Как следствие является то, что газ поставляется только в 9 областей из 14 Казахстана.

Данная ситуация была решена соглашением о своповых поставках в 2006 году по схеме замещения между ПАО «Газпром», НХЛ «Узбекнефтегаз» и АО «НК «КазМунайГаз». Суть данного соглашения заключается в том, что на границе газотраспортных систем Узбекистана и Казахстана ПАО «Газпром» получает природный газ от НХК «Узбекнефтегаз» и передает его в полном объеме HK «КазмунайГаз», данный газ используется для газоснабжения южных регионов Казахстана. В свою очередь НК «КазмунайГаз» переда- ет свой природный газ ПАО «Газпром» в объеме и по цене, равным полученному на границе с Узбекистаном. Благодаря данной схеме происходит взаимообмен необходимого количества природного газа между Казахстаном и Россией [1].

Газовая промышленность Республики Беларусь включает в себя добычу, транспортировку и переработку попутного газа.

Подтвержденные запасы газа составляют примерно 3 млрд. куб. метров [3], данные запасы обеспечивают только 1\% от внутреннего потребления газа. Весь газ, импортируемый в Республику Беларусь, поставляется фактически из России по магистральным газопроводам. Дочернее предприятие ПАО «Газпром», а именно ОАО «Газпром трансгаз Беларусь» занимается поставкой природного газа в Республику.

Согласно договору ЕАЭС «О единых принципах и правилах регулирования деятельности субъектов естественных монополий от 9 декабря 2010 года» транспортировка газа по магистральным и распределительным трубопроводам относится к сферам естественных монополий. Государство РБ осуществляет контроль и регулирование на рынке газа путем установления конечных цен и тарифов на бытовой и сжиженный газ для конечных потребителей.

В силу своего географического положения территория Республики Беларусь выступает транзитной зоной для России при осуществлении внешней торговли между Россией и странами Европы. Данный транзит регулируется соглашением между РФ и РБ от 25.11.2011 года.

Транспортировка газа в Армении и Киргизии очень схожа с ситуацией в Республике Беларусь. Как и в РБ, в Армению и Киргизию газ поставляют дочерние предприятия ПАО «Газпром», а именно ЗАО «Газпром Армения» и ООО «Газпром Кыргызстан».

Дочерние предприятия осуществляют поставку и реализацию природного газа на внутренних рынках Киргизии и Армении для обеспечения всех потребителей газом. Уровень газификации в Армении достиг уже 96\%, а в Киргизии за последние 5 лет вырос на 10\% и составляет 32\%. Объемы продаж газа указаны в таблице 1. Взаиморасчеты по транспортировке газа осуществляются в международной валютедолларах США. Тариф формируется в основном за счет покупательной стоимости природного газа, которую компания пересчитывает ежеме- 
Таблица 1. Объем продаж газа ПАО «Газпром» в страны ЕАЭС, млрд. м $^{3}$ [6]

\begin{tabular}{|c|c|c|c|c|}
\hline & Армения & Республика Беларусь & Казахстан & Кыргызстан \\
\hline 2018 год & 1,8 & 20,0 & 6,2 & 0,3 \\
\hline 2017 год & 1,8 & 18,8 & 4,8 & 0,3 \\
\hline 2016 год & 1,8 & 18,3 & 4,7 & 0,3 \\
\hline
\end{tabular}

сячно по официальному курсу [4].

Согласно протоколу о единых принципах и правилах регулирования деятельности субъектов естественных монополий (Приложение № 20 к договору о ЕАЭС) понятие «доступ к услугам субъектов естественных монополий» определено как оказание услуг субъектами естественных монополий одного государства-члена потребителям другого государства-члена на условиях не менее благоприятных, чем те, на которых предоставляется аналогичная услуга потребителям первого государства-члена при наличии технической возможности [5].

В соответствии с данным протоколом государства-члены ЕАЭС должны разработать и установить перечень законов и нормативных актов, которые обозначат правила регулирования, которые в свою очередь обеспечат доступ к услугам субъектов естественных монополий.

Транспортировка газа в рамках ЕАЭС регулируется также протоколом «о правилах доступа к услугам субъектов естественных монополий с сфере транспортировки газа по газотранспортным системам». Согласно данному протоколу, государства-члены в пределах имеющихся технических возможностей (свободных мощностей) обеспечивают доступ хозяйствующих субъектов других государств-членов к газотранспортным системам, расположенным на своих территори- ях для транспортировки газа. Также в данном протоколе отмечено, что независимые поставщики газа имеют право доступа к газотранспортной системе другого государства-члена на равных условиях с производителями газа.

Деятельность субъектов естественных монополий в рамках ЕАЭС регулируется в положениях договора о ЕАЭС, в котором указано, что любая деятельность подвергается также регулированию для обеспечения независимости применяемых решений, а также преемственности, открытости и прозрачности.

Прозрачность деятельности стран-участниц никакими дополнительными законами не предусмотрена. Однако, соблюдение принципов прозрачности и публичности являются основополагающим при проведении различных реформ в деятельности субъектов естественных монополий. Принципы и механизмы публичности и прозрачности должны быть закреплены на национальном уровне стран участниц, а также на уровне ЕАЭС. Разнообразный опыт стран, входящих в ЕАЭС, будет достаточно важным при вынесении данного направления на наднациональный уровень, а также для создания единой нормативной базы, которая обеспечит повышение публичности и прозрачности деятельности естественных монополий.

\section{Библиографический список}

1. Годовой отчет ООО «Газпром экспорт» за 2016 г. -[Электронный ресурс].- Режим доступа: http://www. gazpromexport.ru/content/file/broshure/ge_ru_2016.pdf

2. Отчет «НЕФТЕГАЗОВАЯ ОТРАСЛЬ РЕСПУБЛИКИ КАЗАХСТАН 2019 г.» -[Электронный ресурс].- Режим доступа: https://kase.kz/files/presentations/ru/KASE_OilGas_industry_2019.pdf

3. Официальный сайт Евразийской экономической комиссии -[Электронный ресурс].- Режим доступа: http:// www.eurasiancommission.org/ru/search/results.aspx?k=\%D1\%81\%D1\%82\%D0\%B0\%D1\%82\%D0\%B8\%D1\%81\% D1\%82\%D0\%B8\%D0\%BA\%D0\%B0\%20\%D0\%B3\%D0\%B0\%D0\%B7

4. Официальный сайт ООО «Газпром Кыргыстан»-[Электронный ресурс].- Режим доступа: https://www. gazprom.kg/\#/tariff?year $=2020 \&$ month $=3$

5. Приложение № 20 к договору о ЕАЭС от 29.05.2014 года -[Электронный ресурс].- Режим доступа: http:// www.consultant.ru/document/cons_doc_LAW_163855/

6. Справочник «Газпром в цифрах 2014-2018 гг»-[Электронный ресурс].- Режим доступа: https://www. gazprom.ru/f/posts/72/692465/gazprom-in-figures-2014-2018-ru.pdf 